\title{
BRAIN ATROPHY PATTERNS IN PATIENTS WITH FRONTOTEMPORAL DEMENTIA: VOXEL-BASED MORPHOMETRY
}

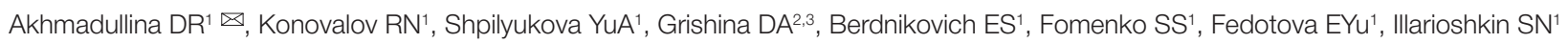

${ }^{1}$ Research Center of Neurology, Moscow, Russia

2 Sechenov First Moscow State Medical University, Moscow, Russia

${ }^{3}$ Pirogov Russian National Research Medical University, Moscow, Russia

Frontotemporal dementia (FTD) is a neurodegenerative disorder characterized by language and behaviour deficits, which is considered the second most common cause of early-onset dementia. Detection of brain atrophy patterns is important for FTD diagnosis. However, the visual assessment of magnetic resonance imaging data may not be sensitive enough requiring the use of objective gray matter (GM) volume determination method. The study was aimed to assess the GM atrophy pattern in patients with FTD compared to control group patients using voxel-based morphometry (VBM). The study included 16 patients with FTD (12 patients with nonfluent agrammatic variant primary progressive aphasia (nfvPPA), three patients with behavioral variant of FTD, and one patient with logopenic variant PPA) and 10 healthy volunteers. VBM of patients with FTD and healthy controls revealed three significant (pFWE-corr $<0.05$ ) atrophy areas in the left inferior frontal, left fusiform, and left supramarginal gyri. Taking into account the predominance of patients with nfvPPA in the group of FTD patients, the additional VBM of this group and control group was carried out, which revealed a distinct atrophy pattern: the reduced GM volume was detected in the left inferior frontal and left middle frontal gyri (pFWE-corr < 0.05). The results obtained indicate that regardless of the clinical variant, there is a certain atrophy pattern characteristic of FTD, which involves both frontotemporal areas and parietal lobe. The example of nfvPPA shows that each variant of the disease is associated with distinct localization of atrophy.

Keywords: frontotemporal dementia, voxel-based morphometry, primary progressive aphasia, behavioral variant frontotemporal dementia

Funding: the study was supported by the Russian Foundation for Basic Research (grant № 19-015-00533).

Author contribution: Akhmadullina DR — clinical assessment, data analysis and interpretation, literature analysis, manuscript writing; Konovalov RN — data analysis and interpretation, study planning and management; Shpilyukova YuA, Grishina DA — clinical assessment, manuscript draft preparation; Berdnikovich ES — clinical assessment; Fomenko SS — data analysis and interpretation, literature analysis, manuscript writing; Fedotova EYu — study planning and management; Illarioshkin SN — study planning and management.

Compliance with ethical standards: the study was approved by the Ethics Committee of the Research Center of Neurology (protocol № 12-7/19 dated December 25, 2019)

$\triangle$ Correspondence should be addressed: Dilyara R. Akhmadullina

Volokolamskoye shosse, 80, Moscow, 125367; akhmadullinadr1@gmail.com

Received: 21.10.2020 Accepted: 18.11.2020 Published online: 08.12.2020

DOI: $10.24075 /$ brsmu.2020.075

\section{ПАТТЕРНЫ АТРОФИИ ГОЛОВНОГО МОЗГА ПРИ ЛОБНО-ВИСОЧНОЙ ДЕМЕНЦИИ: ДАННЫЕ ВОКСЕЛЬ-ОРИЕНТИРОВАННОЙ МОРФОМЕТРИИ}

Д. Р. Ахмадуллина ${ }^{1} \bowtie$, Р. Н. Коновалов ${ }^{1}$, Ю. А. Шпилюкова ${ }^{1}$, Д. А. Гришина ${ }^{2,3}$, Е. С. Бердникович ${ }^{1}$, С. С. Фоменко ${ }^{1}$ Е. Ю. Федотова С. Н. Иллариошкин ${ }^{1}$

${ }^{1}$ Научный центр неврологии, Москва, Россия

2 Первый московский государственный медицинский университет имени И. М. Сеченова, Москва, Россия

${ }^{3}$ Российский национальный исследовательский медицинский университет имени Н. И. Пирогова, Москва, Россия

Лобно-височная деменция (ЛВД) - нейродегенеративное заболевание, вторая по частоте деменция с ранним началом, проявляющаяся речевыми и поведенческими нарушениями. Выявление паттернов атрофии важно для диагностики данной патологии. Однако визуальная оценка данных магнитнорезонансной томографии может быть недостаточно чувствительной, что требует использования объективного метода определения объема серого вещества (СВ). Целью исследования было оценить паттерн атрофии СВ у пациентов с ЛВД в сравнении с контрольной группой при помощи воксельориентированной морфометрии (ВОМ). В исследование включены 16 пациентов с ЛВД (12 - с аграмматическим вариантом первичной прогрессирующей афазии (авППА), три - с поведенческим вариантом ЛВД, один - с логопеническим вариантом ППА) и 10 здоровых добровольцев. При проведении ВОМ в группе ЛВД и контрольной группе выявлено три статистически значимые (pFWE-corr < 0,05) зоны атрофии — в левой нижней лобной извилине, левой фузиформной и левой надкраевой извилинах. В связи с преобладанием в группе ЛВД пациентов с авППА дополнительно проводили ВОМ в этой группе и группе контроля, при которой был выявлен иной паттерн атрофии: уменьшение объема СВ обнаружено в левой нижней лобной и левой средней лобной извилинах (pFWE-corr < 0,05). Полученные результаты показывают, что для ЛВД независимо от клинического варианта характерен свой определенный паттетрн атрофии, захватывающий как лобно-височные отделы, так и теменную долю. На примере авППА было показано, что у каждого из вариантов заболевания локализация атрофического процесса имеет отличный от других характер.

Ключевые слова: лобно-височная деменция, воскель-ориентированная морфометрия, первичная прогрессирующая афазия, поведенческий вариант ЛВД Финансирование: работа выполнена при поддержке гранта РФФИ (номер проекта 19-015-00533).

Вклад авторов: Д. Р. Ахмадуллина - клиническая оценка, анализ и интерпретация данных, анализ литературы, подготовка рукописи; Р. Н. Коновалов анализ и интерпретация данных, планирование и руководство исследованием; Ю. А. Шпилюкова, Д. А. Гришина - клиническая оценка, подготовка черновика рукописи; Е. С. Бердникович - клиническая оценка; С. С. Фоменко - анализ и интерпретация данных, анализ литературы, подготовка рукописи; Е. Ю. Федотова - планирование и руководство исследованием; С. Н. Иллариошкин - планирование и руководство исследованием.

Соблюдение этических стандартов: исследование одобрено этическим комитетом Научного центра неврологии (протокол № $12-7 / 19$ от 25 декабря 2019 г.).

$\bowtie$ Для корреспонденции: Диляра Робертовна Ахмадуллина Волоколамское ш., д. 80, г. Москва, 125367; akhmadullinadr1@gmail.com

Статья получена: 21.10.2020 Статья принята к печати: 18.11.2020 Опубликована онлайн: 08.12.2020

DOI: 10.24075/vrgmu.2020.075 
Frontotemporal dementia (FTD) is a neurodegenerative disorder characterized by behaviour and/or language deficit progression. FTD usually affects people aged 45-65. It is considered to be the second most common cause of early-onset dementia (before age 65), second only to Alzheimer disease (AD) [1].

The following three clinical subtypes of the disorder are distinguished based on the most prevalent deficit: behavioral variant of FTD (bvFTD), semantic variant primary progressive aphasia (svPPA), and nonfluent variant primary progressive aphasia (nfvPPA). The logopenic variant PPA (IvPPA) is typically classified as atypical AD, however, up to 24\% IvPPA cases may be attributed to as FTD based on the pathomorphological investigation results [2]. BvFTD is characterized by progressive deficits in executive function, apathy, behavioural disinhibition, eating disorder, altered motor activity and euphoria. The patients demonstrate risky impulsive behaviour and indifference to people around them. In some of the patients, irritability and sleep disturbances are observed [3]. In patients with primary progressive aphasia (PPA), language impairment is one of the most prominent and disabling manifestations. In patients with SVPPA, the single word comprehension deficits and anomia are observed. The early manifestation is poor comprehension of low frequency words. As symptoms progress, the patients also lose knowledge about more familiar words and objects. The main symptoms of nfvPPA are agrammatisms involoving verbal and subsequently written language, and speech apraxia. As time progresses, difficulties arise with comprehension of syntactically complex sentences, the speech becomes limited, often consisting of single short sentences and subsequently of short phrases. Most patients with IvPPA experience wordfinding difficulties and are unable to repeat long sentences, since the deficit affects the phonological working memory. The above FTD variants manifestations may overlap with motor impairment, such as motor neuron disease (MND) or parkinsonian syndromes (corticobasal syndrome or progressive supranuclear palsy syndrome) [4].

In addition to the clinical manifestations diversity, FTD is characterized by genetic and morphological heterogeneity. The proportion of familial cases is as large as $40 \%$. To date, over 20 genes have been identified, the mutant variants of which are involved in FTD. Yet, the vast majority of genetic cases of the disease are associated with mutations of three genes: C9orf72, GRN, MAPT [5]. Histological analysis of FTD specimen has revealed pathological accumulation of tau protein, TDP-43 or FET family proteins making it possible to classify FTD into three molecular subtypes [6].

Given the prominent FTD heterogeneity, the study and diagnosis of the disease are a major challenge. The existing diagnostic criteria are based on clinical manifestations and neuroimaging data, especially the visual assessment of brain atrophy on magnetic resonance imaging (MRI) and/or computed tomography (CT), or hypoperfusion/hypermetabolism on positron emission tomography (PET) and/or single-photon emission computed tomography (SPECT). The affected areas characteristic of each variant have been distinguished: bilateral frontal and anterior temporal lobe atrophy for bvFTD, frontal and insular lobe atrophy with predominant left hemisphere involvement for nfvPPA, anterior temporal lobe atrophy for SVPPA, and left parietal lobe atrophy with predominant left posterior perisylvian atrophy for IVPPA [7, 8].

However, in recent years it has been shown that visual assessment of MRI data may be insuffucient to identify a characteristic atrophy pattern. According to a number of reports, the accuracy of MRI in diagnosis of bvFTD varies between $59-70 \%[9,10]$. One of the methods for the MRI objectivity improvement is voxel-based morphometry (VBM), the voxel-wise comparison of brain volume between two studied groups in order to detect the significant gray matter (GM) atrophy.

The use of VBM to study FTD has shown that the pathogenetic process is not limited to frontal and temporal lobes. In patients with distinct variants of the disorder, the parietal and occipital areas, cerebellum, insular lobes and subcortical structures may be also affected [11-15]. However, with the new knowlege it becomes clear, that the findings of studies vary significantly. Thus, meta-analysis of publications on the use of VBM in patients with bvFTD revealed the significant frontal and insular lobes atrophy, as well as the bilateral striatum atrophy, but showed no significant temporal lobes lesions (one of the bvFTD diagnosis criteria) reported by a number of authors [16].

Moreover, some reports show that clinical manifestations of PPA may vary depending on the patient's native language, therefore, the FTD-associated atrophy patterns may vary depending on the studied population [17, 18]. However, no studies of characteristic FTD-associated atrophy features in Russian population have been performed.

The study was aimed to reveal the characteristic patterns of brain atrophy common to distinct FTD variants in the Russian population.

\section{METHODS}

The study was carried out at the Research Center of Neurology. Inclusion criteria: patients who fulfilled the diagnostic criteria of FTD; age over 18 years. Exclusion criteria: contraindications for $\mathrm{MRl}$; serious health condition requiring the advanced life support; structural focal brain lesions (tumors, effects of cerebrovascular accident or traumatic brain injury, etc.). A cohort of 16 FTD patients (6 men and 10 women; average age $61.2 \pm 9.4$ years), and 10 healthy volunteers ( 4 men and 6 women; average age $55.6 \pm 11.3$ years) were included in the study. The groups were matched for age and gender.

Twelve $(68.75 \%)$ patients of index group were diagnosed with nfvPPA, three patients (18.75\%) were diagnosed with bvFTD, and one patient (6.25\%) had IVPPA. The patient with IVPPA underwent lumbar puncture with amyloid- $\beta$ level assessment. The normal amyloid- $\beta$ level value made it possible to exclude AD. One of the patients with nfvPPA had signs of MND (FTD-MND phenotype). The average age of nfvPPA patients was $60.6 \pm 7.5$ years, the four of them were males.

At the time of the study, the disease duration ranged from 12 to 84 months, and the average duration of the disease was $47.6 \pm 21.3$ months. The disease severity was assessed using the Frontotemporal Dementia Rating Scale (FTD-FRS) [19]: 3 patients were rated as having very mild FTD, 4 patients had mild FTD, and 7 patients were diagnosed with moderate FTD; the group also included one patient with severe and one patient with extremely severe FTD. The total Frontal Assessment Battery (FAB) score ranged from 3 to 15 , the average value was $9.3 \pm 3.9$. It was difficult to use the Montreal Cognitive Assessment (MoCA) test in 8 patients due to severe language and/or behaviour deficits (apathy, restlessness, refusal to perform tests). The average score of patients tested was $22.25 \pm 6.04$. In addition, all patients were tested for literal and semantic verbal fluency. The significant literal and semantic verbal fluency decline was revealed (an average of 3 and 7 words per minute, respectively).

MRI of the brain in the 3D-T1 MPR (multiplanar reconstruction) mode was performed in all patients using the Magnetom Verio 3T system (Siemens; Germany). The MRI data 
post-processing and statistical analysis were carried out using the SPM12 software (Statistical Parametric Mapping; Institute of Neurology, UK) written using Matlab R2019b (Mathworks; USA).

Post-processing included spatial normalization of images to $\mathrm{MNI}$ (Montreal Neurological Institute) reference space, MR images segmenting into GM, white matter and cerebrospinal fluid using the DARTEL (Diffeomorphic Anatomical Registration Through Exponentiated Lie Algebra) algorithm, as well as spatial smoothing using the isotropic Gaussian filter kernel with full width at half maximum (FWHM) size $8 \mathrm{~mm}$ in order to align the individual structural characteristics.

The Easy Volumes utility (Institute of Neurology; UK) was used to calculate total GM volume, as well as bilateral GM volume in frontal, temporal, parietal, occipital, insular lobes and basal ganglia.

VBM data vizualiation, statistical analysis, data withdrawal and coordinates localization were performed using the xjView software [20].

The assessment of VBM results included cluster analysis using the two-sample t-test with the whole brain voxel-wise comparison of GM volume between the studied groups. The threshold for the individual voxels of the cluster was set to $p<0.0001$. The analysis included the GM clusters of cerebral hemispheres with minimum area volume of $\geq 100$ voxels and significance level of $p<0.05$ adjusted for multiple comparisons to control the family-wise error (FWE) rate. The analysis of the results was performed at the cluster and peak levels.

Statistical data processing was performed using the IBM SPSS Statistics 23.0 software (IBM; USA). The differences in the brain GM volume between two groups were assessed using the Mann-Whitney $U$ test (Bonferroni adjusted). The relationship between clinical data and brain GM atrophy was defined by correlation analysis using the Spearman's rank correlation coefficient.

\section{RESULTS}

VBM revealed a significant decline in GM volume in the left inferior frontal, supramarginal and fusiform gyri in patients with FTD compared to controls (Table 1, Fig.). The greatest degree of atrophy was observed in the left inferior frontal gyrus.
Due to the significant prevalence of nfvPPA among patients with FTD, the additional analysis of this group was carried out. VBM revealed significant degree of atrophy in the small areas of left middle and inferior frontal gyri in patients with nfvPPA compared to controls (see Table 1).

At the next stage the calculation of total GM volume and GM volume in frontal, temporal, parietal, occipital and insular lobes, as well in basal ganglia of the right and left hemispheres, was carried out in both groups. The differences between two groups were significant $(p<0.05)$ in all listed areas (Table 2).

Correlation analysis revealed a significant negative correlation between the left temporal lobe GM volume and the duration of the disease (Spearman's rank correlation coefficient -0.53; $p=0.035)$. No correlations with other clinical manifestations and neuropsychological findings (total MoCA and FAB score, semantic and literal verbal fluency, disease severity) were detected.

\section{DISCUSSION}

The study showed that in the group of patients with FTD the significant GM volume decline was observed in the following areas: left inferior frontal, supramarginal and fusiform gyri.

The greatest cluster of atrophy was detected in the left inferior frontal gyrus, which is the location of Broca's area involved in the motor-phonological network regulation, as well as in the complex grammatical and syntactic constructions comprehension and production. Atrophy of the described area is one of the major signs of nfvPPA, which correlates with overall severity of aphasia and severity of agrammatisms [21, 22]. The greater degree of atrophy in the left inferior frontal gyrus may be explained by the predominance of patients with this phenotype in the FTD group.

The fusiform gyrus involvement has been reported for all PPA variants and bvFTD $[22,23]$. Together with orbitofrontal cortex, amygdala and other temporal association areas, the fusiform gyrus forms a perceptual system responsible for recognition and analysis of others' social signals (for example, understanding of facial expressions) [24], i. e. plays a part in the social behaviour production. Furthermore, it has been shown, that the fusiform gyri atrophy in patients bvFTD correlates with the severity of disinhibition [25].

Table 1. Areas of significant (pFWE-corr < 0.05) gray matter volume reduction based on VBM data

\begin{tabular}{|c|c|c|c|c|c|c|}
\hline \multirow{2}{*}{ Localization of atrophy } & \multicolumn{2}{|c|}{ Cluster level } & \multicolumn{3}{|c|}{ Peak level } & \multirow{2}{*}{$\begin{array}{c}\text { MNI peak coordinates } \\
(x, y, z), \mathrm{mm}\end{array}$} \\
\hline & $\begin{array}{l}\text { Degree of atrophy } \\
\text { (voxels) }\end{array}$ & pFWE-corr & $\mathrm{T}$ & z & pFWE-corr (peak level) & \\
\hline \multicolumn{7}{|c|}{ FTD group < control group } \\
\hline \multirow{2}{*}{ Inferior frontal gyrus, S } & \multirow{2}{*}{8198} & \multirow{2}{*}{$<0.001$} & 11.14 & 6.47 & $<0.001$ & $-36,3,24$ \\
\hline & & & 9.66 & 6.05 & $<0.001$ & $-44,14,17$ \\
\hline \multirow{3}{*}{ Supramarginal gyrus, S } & \multirow{3}{*}{350} & \multirow{3}{*}{$<0.001$} & 7.66 & 5.35 & 0.003 & $-47,-41,35$ \\
\hline & & & 6.57 & 4.88 & 0.021 & $-35,-44,44$ \\
\hline & & & 6.54 & 4.87 & 0.022 & $-33,-39,33$ \\
\hline \multirow{2}{*}{ Fusiform gyrus, $\mathrm{S}$} & \multirow{2}{*}{136} & \multirow{2}{*}{0.001} & 7.04 & 5.09 & 0.009 & $-54,-8,-27$ \\
\hline & & & 6.91 & 5.03 & 0.011 & $-57,-17,-23$ \\
\hline \multicolumn{7}{|c|}{ nfvPPA group < control group } \\
\hline \multirow{2}{*}{ Middle frontal gyrus, S } & \multirow{2}{*}{122} & \multirow{2}{*}{$<0.001$} & 9.24 & 5.63 & 0.002 & $-30,38,33$ \\
\hline & & & 7.56 & 5.08 & 0.023 & $-30,47,23$ \\
\hline \multirow{3}{*}{ Inferior frontal gyrus, S } & \multirow{3}{*}{155} & \multirow{3}{*}{$<0.001$} & 8.46 & 5.39 & 0.006 & $-50,14,17$ \\
\hline & & & 7.95 & 5.21 & 0.013 & $-53,6,15$ \\
\hline & & & 7.89 & 5.19 & 0.014 & $-56,-3,17$ \\
\hline
\end{tabular}

Note: $S$ - left. 

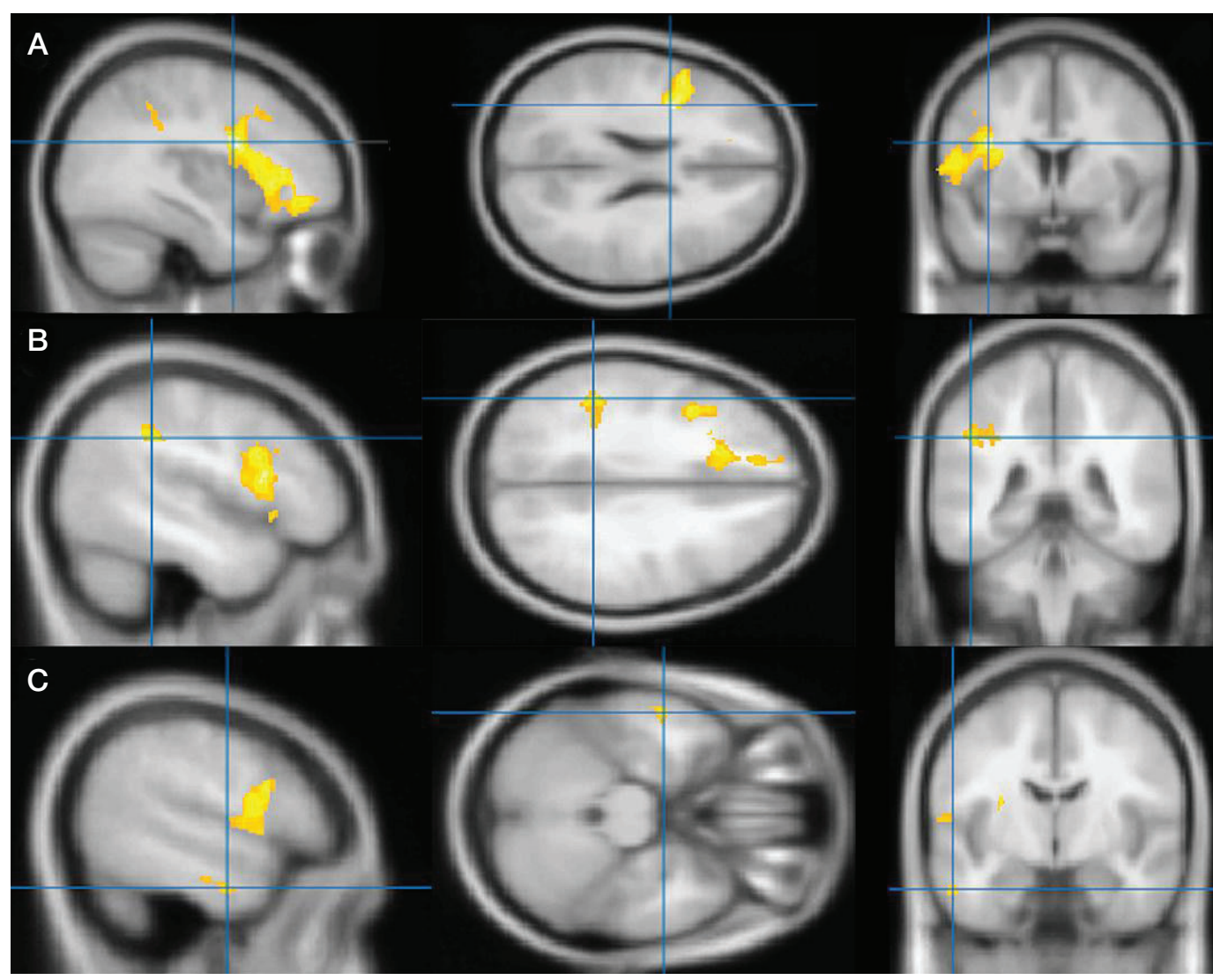

Fig. Localization of significant (pFWE-corr < 0.05) GM volume decline in patients with FTD compared to control group. A. Lleft inferior frontal gyrus. B. Left supramarginal gyrus. C. Left fusiform gyrus. From left to right: sagittal, axial and coronal slices

The supramarginal gyrus is involved in phonological shortterm memory and phonological speech processing. It also appears to be connected to brain areas responsible for speech motor control [26]. Although the affected supramarginal gyrus is typically considered a neuroimaging sign of IVPPA, some papers report the supramarginal gyrus atrophy in patients with nonfluent agrammatic and semantic variant PPA [7, 27, 28].

Since the nfvPPA phenotype was observed in vast majority of patients of the FTD group, it might be assumed that the GM volume decline in all three areas was associated with nfvPPA, while the other variants' contribution was not of comparable importance. However, VBM in patients with nfvPPA and control group patients revealed the different pattern of atrophy: the affected left inferior frontal and middle frontal gyri. The involvement of left inferior frontal gyrus was less extensive and pronounced compared to the FTD group, while the affected middle frontal gyrus was restricted to that particular group. The similar pattern of atrophy has been previously reported, for example, in the meta-analysis performed in 2007, which revealed reduced volume of opercular part of inferior frontal gyrus, middle frontal gyrus, lentiform nucleus and superior temporal gyri [15], and the other study, which revealed the affected left precentral gyrus in addition to the listed above areas [29]. The decline in inferior Table 2. Gray matter volume in patients with FTD and control group frontal gyrus atrophy degree and severity might be associated

\begin{tabular}{|l|c|c|c|}
\hline \multirow{2}{*}{ Gray matter volume } & FTD & Control & $\begin{array}{c}\text { Significance level, Mann-Whitney } \\
\text { test }(p)\end{array}$ \\
\cline { 2 - 4 } & Median [LQ; UQ] & Median [LQ; UQ] & $<0.001$ \\
\hline Total & $508.4[474.8 ; 534.2]$ & $656.2[597.6 ; 721.0]$ & $<0.001$ \\
\hline Frontal lobe, S & $33.4[30.0 ; 35.4]$ & $53.4[47.1 ; 56.5]$ & $<0.001$ \\
\hline Frontal lobe, D & $40.2[35.7 ; 44.6]$ & $56.6[48.7 ; 59.0]$ & $<0.001$ \\
\hline Temporal lobe, S & $33.4[31.1 ; 39.4]$ & $50.0[43.4 ; 54.8]$ & 0.002 \\
\hline Temporal lobe, D & $41.4[35.5 ; 47.2]$ & $51.9[46.2 ; 57.8]$ & $<0.001$ \\
\hline Parietal lobe, S & $30.3[28.1 ; 35.7]$ & $46.5[38.5 ; 49.3]$ & 0.003 \\
\hline Parietal lobe, D & $38.0[33.6 ; 41.8]$ & $49.2[41.8 ; 52.9]$ & $<0.001$ \\
\hline Occipital lobe, S & $14.8[13.4 ; 16.7]$ & $20.3[17.4 ; 23.4]$ & 0.003 \\
\hline Occipital lobe, D & $12.4[11.0 ; 13.0]$ & $15.6[13.2 ; 16.4]$ & $<0.001$ \\
\hline Insular lobe, S & $5.5[5.2 ; 6.0]$ & $7.9[7.1 ; 8.4]$ & 0.001 \\
\hline Insular lobe, D & $6.3[5.5 ; 7.0]$ & $7.9[7.2 ; 8.5]$ & $<0.001$ \\
\hline Basal ganglia, S & $8.0[7.0 ; 9.4]$ & $12.1[10.8 ; 12.5]$ & 0.001 \\
\hline Basal ganglia, D & $10.0[7.8 ; 10.4]$ & $12.0[10.9 ; 12.6]$ & \\
\hline
\end{tabular}

Note: $L Q$ - lower quartile, UQ — upper quartile, S — left, D — right. 
with more severe disorder in patients with bvFTD and IvPPA (the average FTD-FRS score was 2.36 among patients with nfvPPA and -0.04 among other patients) given the similar average duration of the disease at the time of assessment (47.5 months in patients with nfvPPA, 48 months in other patients).

Thus, the atrophy of left fusiform and supramarginal gyri detected during the whole group analysis can not be explained by the sampling bias toward the patients with nfvPPA, and is likely to result from the listed areas' lesion in all studied variants of the disease.

The study of correlations of clinical and neuropsychological data with the volume of distinct lobes and subcortical structures revealed only one significant negative correlation between the volume of left temporal lobe and the duration of the disease. The involvement of the left temporal lobe may be explained by the left fusiform gyrus lesion. However, taking into account the prevalence of nfvPPA and greater degree of atrophy in the left inferior frontal gyrus, the correlation of the left frontal gyrus volume with the severity of the disease and speech fluency impairment might be expected, reported in a number of papers. The lack of such correlation may be due to several factors. First, not the volume of distinct gyri, but the volume of entire lobes was taken into account during the analysis. Second, the severity of the disease was assessed using the Frontotemporal Dementia Rating Scale (the questionnaire, which includes the whole range of symptoms), whereas given the predominance of PPA it would be judicious to perform additional assessment of the patients' condition using the aphasia severity scales. Lack of correlations in accordance with the FAB and MoCA scores may be also due to the listed scales specialization: these scales are more focused on the characteristic of bvFTD executive functions impairment detection than on the speech impairment detection.

It should be noted that our study had a number of limitations: small sample size, unequal distribution of patients with distinct FTD variants within the group, and lack of patients with sVPPA. We did not compare the distinct variants of the disease (nfvPPA, bvFTD, IvPPA) due to small number of patients with bvFTD and IVPPA. That did not allow us to draw the conclusion about the differences between atrophy patterns characteristic of nfvPPA and other FTD variants. These limitations should be taken into account when planning the further study of the issue.

\section{CONCLUSION}

The VBM study revealed the affected left inferior frontal, supramarginal and fusiform gyri in patients with FTD compared to healthy controls. The limited atrophy pattern which involves left middle frontal and inferior frontal gyri is characteristic of nfvPPA. The results obtained are consistent with the khowlege about the functional anatomy of speech function and social behaviour. Our results are partially consistent with the previous studies reported by foreign authors. However, these studies have revealed the greater involvement of gray matter and the larger number of affected brain areas. Further study of the neuroimaging FTD signs is required in the larger patients' sample to confirm the obtained results.

\section{References}

1. Finger EC. Frontotemporal Dementias. Continuum. 2016; 22: 464-89.

2. Bergeron D, Gorno-Tempini ML, Rabinovici GD, Santos-Santos MA, Seeley W, Miller BL, et al. Prevalence of amyloid- $\beta$ pathology in distinct variants of primary progressive aphasia. Ann Neurol. 2018; 84 (5): 729-40.

3. Grishina DA, Yakhno NN, Zakharov W. Emotional, affective and behavioral disorders in a behavioral variant of frontotemporal dementia. S.S. Korsakov Journal of Neurology and Psychiatry. 2017; 117 (11): 13

4. Olney NT, Spina S, Miller BL. Frontotemporal Dementia. Neurol Clin. 2017; 35 (2): 339-74.

5. Shpilyukova YuA, Fedotova EYu, Illarioshkin SN. Genetic diversity of frontotemporal dementia. Molecular Biology. 2020; 54 (1): 17-28.

6. Mackenzie IRA, Neumann M. Molecular neuropathology of frontotemporal dementia: insights into disease mechanisms from postmortem studies. J Neurochem. 2016; 54-70.

7. Gorno-Tempini ML, Hillis AE, Weintraub S, Kertesz A, Mendez M, Cappa SF, et al. Classification of primary progressive aphasia and its variants. Neurology. 2011; 76 (11): 1006-14.

8. Rascovsky K, Hodges JR, Knopman D, Mendez MF, Kramer JH, Neuhaus J, et al. Sensitivity of revised diagnostic criteria for the behavioural variant of frontotemporal dementia. Brain. 2011 Sep; 134 (9): 2456-77.

9. Vijverberg EGB, Wattjes MP, Dols A, Krudop WA, Möller C, Peters A, et al. Diagnostic Accuracy of MRI and Additional [18F]FDG-PET for Behavioral Variant Frontotemporal Dementia in Patients with Late Onset Behavioral Changes. J Alzheimer's Dis. 2016; 53 (4): 1287-97.

10. Harper L, Fumagalli GG, Barkhof F, Scheltens P, O'Brien JT, Bouwman $F$, et al. MRI visual rating scales in the diagnosis of dementia: Evaluation in 184 post-mortem confirmed cases. Brain. 2016; 139 (4): 1211-25.

11. Pan PL, Song W, Yang J, Huang R, Chen K, Gong QY, et al. Gray Matter Atrophy in Behavioral Variant Frontotemporal Dementia: A Meta-Analysis of Voxel-Based Morphometry Studies. Dement
Geriatr Cogn Disord. 2012; 33 (2-3): 141-8.

12. Rohrer JD, Ridgway GR, Modat M, Ourselin S, Mead S, Fox NC, et al. Distinct profiles of brain atrophy in frontotemporal lobar degeneration caused by progranulin and tau mutations. Neuroimage. 2010; 53 (3): 1070-6.

13. Mahoney CJ, Beck J, Rohrer JD, Lashley T, Mok K, Shakespeare T, et al. Frontotemporal dementia with the C9ORF72 hexanucleotide repeat expansion: clinical, neuroanatomical and neuropathological features. Brain. 2012; 135 (3): 736-50.

14. Josephs KA, Whitwell JL, Parisi JE, Petersen RC, Boeve BF, Jack CR, et al. Caudate atrophy on MRI is a characteristic feature of FTLDFUS. Eur J Neurol. 2010; 17 (7): 969-75.

15. Schroeter ML, Raczka K, Neumann J, Yves von Cramon D. Towards a nosology for frontotemporal lobar degenerations - A meta-analysis involving 267 subjects. Neuroimage. 2007 Jul; 36 (3): 497-510.

16. Seeley WW. Behavioral Variant Frontotemporal Dementia. Contin Lifelong Learn Neurol. 2019 Feb; 25 (1): 76-100.

17. Folegatti A, Pia L, Berti A, Cubelli R. Stress assignment errors in surface dyslexia: Evidence from two Italian patients with a selective deficit of the orthographic input lexicon. Behav Neurol. 2015; 2015: 1-8.

18. Canu E, Agosta F, Battistella G, Spinelli EG, DeLeon J, Welch AE, et al. Speech production differences in English and Italian speakers with nonfluent variant PPA. Neurology. 2020; 94 (10): e1062-72.

19. Shpilyukova YuA, Yusupova DG, Akhmadullina DR, Polekhina NV, Naminov AV, Sinelnikov ME, et al. Frontotemporal dementia rating scale (FTD-FRS): linguistic and cultural adaptation in Russia. Annals of Clinical and Experimental Neurology. 2020; 14 (2): 82-7.

20. xjView. Version 9.6 [software]. Available from: http://www. alivelearn.net/xjview.

21. Tetzloff KA, Utianski RL, Duffy JR, Clark HM, Strand EA, Josephs $K A$, et al. Quantitative analysis of agrammatism in agrammatic primary progressive aphasia and dominant apraxia of speech. $J$ Speech, Lang Hear Res. 2018; 61 (9): 2337-46. 
22. Whitwell JL, Duffy JR, Strand EA, Xia R, Mandrekar J, Machulda $\mathrm{MM}$, et al. Distinct regional anatomic and functional correlates of neurodegenerative apraxia of speech and aphasia: An MRI and FDG-PET study. Brain Lang. 2013; 125 (3): 245-52.

23. Brambati SM, Amici S, Racine CA, Neuhaus J, Miller Z, Ogar J, et al. Longitudinal gray matter contraction in three variants of primary progressive aphasia: A tenser-based morphometry study Neurolmage Clin. 2015; 8: 345-55.

24. Bickart KC, Brickhouse M, Negreira A, Sapolsky D, Barrett LF, Dickerson BC. Atrophy in distinct corticolimbic networks in frontotemporal dementia relates to social impairments measured using the social impairment rating scale. J Neurol Neurosurg Psychiatry. 2014; 85 (4): 438-48.

25. Sheelakumari R, Bineesh C, Varghese T, Kesavadas C, Verghese J, Mathuranath PS. Neuroanatomical correlates of apathy and disinhibition in behavioural variant frontotemporal dementia. Brain

\section{Литература}

1. Finger EC. Frontotemporal Dementias. Continuum. 2016; 22: 464-89.

2. Bergeron D, Gorno-Tempini ML, Rabinovici GD, Santos-Santos MA, Seeley W, Miller BL, et al. Prevalence of amyloid- $\beta$ pathology in distinct variants of primary progressive aphasia. Ann Neurol. 2018; 84 (5): 729-40.

3. Гришина Д. А., Яхно Н. Н., Захаров В. В. Эмоциональные, аффективные и поведенческие нарушения при поведенческой форме лобно-височной деменции. Журнал неврологии и психиатрии им С. С. Корсакова. 2017; 117 (11): 13.

4. Olney NT, Spina S, Miller BL. Frontotemporal Dementia. Neuro Clin. 2017; 35 (2): 339-74.

5. Шпилюкова Ю. А., Федотова Е. Ю., Иллариошкин С. Н. Генетическое разнообразие лобно-височной деменции Молекулярная биология. 2020; 54 (1): 17-28.

6. Mackenzie IRA, Neumann M. Molecular neuropathology of frontotemporal dementia: insights into disease mechanisms from postmortem studies. J Neurochem. 2016; 54-70.

7. Gorno-Tempini ML, Hillis AE, Weintraub S, Kertesz A, Mendez M, Cappa SF, et al. Classification of primary progressive aphasia and its variants. Neurology. 2011; 76 (11): 1006-14.

8. Rascovsky K, Hodges JR, Knopman D, Mendez MF, Kramer JH Neuhaus J, et al. Sensitivity of revised diagnostic criteria for the behavioural variant of frontotemporal dementia. Brain. $2011 \mathrm{Sep}$ 134 (9): 2456-77.

9. Vijverberg EGB, Wattjes MP, Dols A, Krudop WA, Möller C, Peters A, et al. Diagnostic Accuracy of MRI and Additional [18FFFDG-PET for Behavioral Variant Frontotemporal Dementia in Patients with Late Onset Behavioral Changes. J Alzheimer's Dis. 2016; 53 (4): 1287-97

10. Harper L, Fumagalli GG, Barkhof F, Scheltens P, O'Brien JT, Bouwman F, et al. MRI visual rating scales in the diagnosis of dementia: Evaluation in 184 post-mortem confirmed cases. Brain. 2016; 139 (4): 1211-25.

11. Pan PL, Song W, Yang J, Huang R, Chen K, Gong QY, et al. Gray Matter Atrophy in Behavioral Variant Frontotemporal Dementia: A Meta-Analysis of Voxel-Based Morphometry Studies. Dement Geriatr Cogn Disord. 2012; 33 (2-3): 141-8.

12. Rohrer JD, Ridgway GR, Modat M, Ourselin S, Mead S, Fox NC, et al. Distinct profiles of brain atrophy in frontotemporal lobar degeneration caused by progranulin and tau mutations. Neuroimage. 2010; 53 (3): 1070-6.

13. Mahoney CJ, Beck J, Rohrer JD, Lashley T, Mok K, Shakespeare T, et al. Frontotemporal dementia with the C9ORF72 hexanucleotide repeat expansion: clinical, neuroanatomical and neuropathological features. Brain. 2012; 135 (3): 736-50.

14. Josephs KA, Whitwell JL, Parisi JE, Petersen RC, Boeve BF, Jack CR, et al. Caudate atrophy on MRI is a characteristic feature of FTLDFUS. Eur J Neurol. 2010; 17 (7): 969-75.

15. Schroeter ML, Raczka K, Neumann J, Yves von Cramon D. Towards a nosology for frontotemporal lobar degenerations - A meta-analysis involving 267 subjects. Neuroimage. 2007 Jul; 36 (3): 497-510.

16. Seeley WW. Behavioral Variant Frontotemporal Dementia. Contin
Imaging Behav. 2020 Oct; 14 (5): 2004-11.

26. Oberhuber M, Hope TMH, Seghier ML, Parker Jones O, Prejawa S, Green DW, et al. Four Functionally Distinct Regions in the Left Supramarginal Gyrus Support Word Processing. Cereb Cortex. 2016; 26 (11): 4212-26.

27. Preiß D, Billette OV, Schneider A, Spotorno N, Nestor PJ. The atrophy pattern in Alzheimer-related PPA is more widespread than that of the frontotemporal lobar degeneration associated variants. Neurolmage Clin. 2019; 24: 101994.

28. Bisenius S, Neumann J, Schroeter ML. Validating new diagnostic imaging criteria for primary progressive aphasia via anatomical likelihood estimation meta-analyses. Eur J Neurol. 2016; 23 (4): 704-12.

29. Ballard KJ, Savage S, Leyton CE, Vogel AP, Hornberger M, Hodges JR. Logopenic and Nonfluent Variants of Primary Progressive Aphasia Are Differentiated by Acoustic Measures of Speech Production. PLoS One. 2014; 9 (2): e89864.

Lifelong Learn Neurol. 2019 Feb; 25 (1): 76-100.

17. Folegatti $A$, Pia L, Berti A, Cubelli R. Stress assignment errors in surface dyslexia: Evidence from two Italian patients with a selective deficit of the orthographic input lexicon. Behav Neurol. 2015; 2015: 1-8.

18. Canu E, Agosta F, Battistella G, Spinelli EG, DeLeon J, Welch AE, et al. Speech production differences in English and Italian speakers with nonfluent variant PPA. Neurology. 2020; 94 (10): e1062-72.

19. ШпилюковаЮ. А., ЮсуповаД. Г., АхмадуллинаД. Р., ПолехинаН. В., Наминов А. В., Синельников М. В. и соавт. Шкала оценки тяжести лобно-височной деменции (Frontotemporal dementia rating scale - FTD-FRS): лингвокультурная адаптация в России. Анналы клинической и экспериментальной неврологии. 2020; 14 (2): 82-7.

20. xjView. Version 9.6 [software]. Available from: http://www. alivelearn.net/xjview.

21. Tetzloff KA, Utianski RL, Duffy JR, Clark HM, Strand EA, Josephs $K A$, et al. Quantitative analysis of agrammatism in agrammatic primary progressive aphasia and dominant apraxia of speech. $J$ Speech, Lang Hear Res. 2018; 61 (9): 2337-46.

22. Whitwell JL, Duffy JR, Strand EA, Xia R, Mandrekar J, Machulda $\mathrm{MM}$, et al. Distinct regional anatomic and functional correlates of neurodegenerative apraxia of speech and aphasia: An MRI and FDG-PET study. Brain Lang. 2013; 125 (3): 245-52.

23. Brambati SM, Amici S, Racine CA, Neuhaus J, Miller Z, Ogar J, et al. Longitudinal gray matter contraction in three variants of primary progressive aphasia: A tenser-based morphometry study. Neurolmage Clin. 2015; 8: 345-55.

24. Bickart KC, Brickhouse M, Negreira A, Sapolsky D, Barrett LF, Dickerson BC. Atrophy in distinct corticolimbic networks in frontotemporal dementia relates to social impairments measured using the social impairment rating scale. J Neurol Neurosurg Psychiatry. 2014; 85 (4): 438-48.

25. Sheelakumari R, Bineesh C, Varghese T, Kesavadas C, Verghese J, Mathuranath PS. Neuroanatomical correlates of apathy and disinhibition in behavioural variant frontotemporal dementia. Brain Imaging Behav. 2020 Oct; 14 (5): 2004-11.

26. Oberhuber M, Hope TMH, Seghier ML, Parker Jones O, Prejawa S, Green DW, et al. Four Functionally Distinct Regions in the Left Supramarginal Gyrus Support Word Processing. Cereb Cortex. 2016; 26 (11): 4212-26.

27. Preiß D, Billette OV, Schneider A, Spotorno N, Nestor PJ. The atrophy pattern in Alzheimer-related PPA is more widespread than that of the frontotemporal lobar degeneration associated variants. Neurolmage Clin. 2019; 24: 101994.

28. Bisenius S, Neumann J, Schroeter ML. Validating new diagnostic imaging criteria for primary progressive aphasia via anatomical likelihood estimation meta-analyses. Eur J Neurol. 2016; 23 (4): 704-12.

29. Ballard KJ, Savage S, Leyton CE, Vogel AP, Hornberger M, Hodges JR. Logopenic and Nonfluent Variants of Primary Progressive Aphasia Are Differentiated by Acoustic Measures of Speech Production. PLoS One. 2014; 9 (2): e89864. 